\title{
BIOECOLOGICAL CHARACTERISTICS PLANTS OF SALVIA VERTICILLATA L. UNDER CONDITION FOREST-STEPPE ZONE OF UKRAINE
}

\author{
Korablova Olga*1 ${ }^{1}$, Rakhmetov Dzhamal ${ }^{1}$, Frolova Nataliia ${ }^{2}$, \\ Yushchenko Nataliia ${ }^{2}$, Shanaida Mariia ${ }^{3}$, Svydenko Ludmyla ${ }^{4}$ \\ ${ }^{1}$ M.M.Gryshko National Botanical of National Academy of Science of Ukraine, Kyiv, Ukraine \\ ${ }^{2}$ National University of Food Technologies, Kyiv, Ukraine \\ ${ }^{3}$ I. Gorbachevsky National Medical University, Ternopil, Ukraine \\ ${ }^{4}$ Institute of Rice of National Academy of Agrarian Science of Ukraine, Skadovsk, Ukraine
}

Received: 12. 7. 2019 Revised: 16. 11. 2019 Published: 30.11. 2019

The genus Salvia L., is one of the largest in the Lamiaceae family. Salvia verticillata L. is used for various diseases in folk medicine and as honey plants. The purpose of the work is to investigate the variability of bioecological and morphological characteristics of plants and seeds of the species $S$. verticillata, to select high-yield forms for use in Ukraine at the level of cultivars. Conducted comparative studies of biometric and morphological features, quantitative and qualitative characteristics seeds of the plants species $S$. verticillata were determined. It is established that the mass of 1,000 seeds of $S$. verticillata species is rather unstable during the years of storage. The mass of 1,000 seeds $S$. verticillata decreases significantly after three years of storage. It is established that in the first two years storage of seeds S. verticillata its germination is maintained at a fairly high level, in the third year it decreases three times, in 4-5 years the single seeds germinate, and for the sixth year the germination is equal to zero. Depending on the row spacing and the number of cuts, yield and productivity of the plants $S$. verticillata were determined both for fresh green mass and seeds. Biometric studies have shown the relationship between the row spacing and the number of generative shoots and inflorescence on plants, and the productivity of plantings. At a feeding area of $35 \times 15 \mathrm{~cm}$, the plants had thin stems $\left(112.5 \pm 3.6 \mathrm{pc} / \mathrm{m}^{2}\right)$ and the lowest seed productivity $(0.8 \mathrm{~g} /$ plant $)$. At a feeding area of $55 \times 15 \mathrm{~cm}$, the plants had more thick stems $\left(152.0 \pm 4.0 \mathrm{pc} / \mathrm{m}^{2}\right)$ and the highest seed productivity (up to $5 \mathrm{~g} / \mathrm{plant}$ ). Plants grown with rows of $55 \mathrm{~cm}$ had the highest productivity of green mass. It is proved that under conditions of the Forest-Steppe zone during the first flowering raw material of plants species $S$. verticillata for technical processing should be harvested, and during the second flowering - seeds should be collected. Seeds of $S$. verticillata during storage should be updated every 2-3 years. On the basis of gene pool of spicy aromatic plants and introductory populations in the NBS of NASU for the first time in Ukraine the cultivar S. verticillata'Musketeer' was created and was entered in the Register of Varieties of Ukraine in 2016.

Keywords: Salvia verticillata, bioecological characteristics, seeds, green mass, productivity

\footnotetext{
*Corresponding author: Korablova Olga, M.M.Gryshko National Botanical, National Academy of Science of Ukraine, Timiryazevska 1, 01014 Kyiv, Ukraine $\triangle$ okorablova.ukr@net
} 


\section{Вступ}

Рід Salvia L., що належить до підродини Nepetoideae, є одним з найбільших у родині Lamiaceae, і налічує близько 900 видів (Kovalova, 2009; Dolya et al., 2012). Велика кількість рослин серед видів роду $\epsilon$ ароматичними, що робить їх важливими з комерційної точки зору. Представники роду містять значну кількість ефірної олії та використовуються як кулінарні трави і ароматизатори при виготовленні страв і напоїв (Lawrence, 1992), парфумерних виробів (Ahmed, 2011). Фітосировина видів роду Salvia та отримані з неї біологічно активні сполуки, займають важливе місце у виготовленні сучасних лікарських засобів та харчових продуктів. Деякі з них використовують як стимулятори і регулятори системи травлення з додатковими антисептичними властивостями. Інші види рослин Salvia відомі своїми жарознижуючими, знеболюючими та відхаркувальними властивостями і можуть бути застосовані в терапії грипу і простуди. Деякі види використовують у терапії психозів, депресій, неврозів у зв'язку з седативними властивостями відповідних відварів (Okuno, 2004; Naghibi, 2005). На вітчизняному фармацевтичному ринку, у фітотерапії та народній медицині поширені препарати, в яких використовується надземна частина деяких видів шавлії, переважно S. officinalis L. та S. sclarea L. Вони також використовуються у харчовій промисловості у складі пряних сумішей для ароматизації продуктів харчування (Korablova and Rakhmetov, 2012). Ряд видів Salvia використовують як декоративні рослини (Cervelli, 2011) та як фітосировину для лікарських засобів (Okuno, 2004; Naghibi, 2005; Kyseleva and Smyrnova, 2009).

Шавлію кільчасту S. verticillata L. використовують за різних захворювань у народній медицині та як медоносні рослини (Liu, 2011). Дослідження останніх років свідчать також про значний антидіабетичний ефект при використанні засобів із S. verticillata (Attitalla, 2011; Eidi, 2011; Semenchenko, 2014; Mahdizadeh, 2018). Однак, детальних досліджень культури в Україні не проводили. Саме тому, на нашу думку, S. verticillata потребує більш ретельного вивчення в сенсі їі вирощування та комплексного використання у різних галузях промисловості.

Метою роботи було дослідити варіабельність біоекологічних та морфологічних особливостей рослин і насіння виду S. verticillata, відібрати високопродуктивні форми для використання в Україні на рівні сортів.

\section{Матеріали та методи}

Експериментальна робота виконана в період з 2012 по 2018 роки в умовах Лісостепу в Національному ботанічному саду ім. М. М. Гришка НАН України із залученням колекційних зразків та рослин Salvia verticillata L., інтродукованих з Тернополя та Скадовська (Rakhmetov et al., 2015).

Для вивчення морфобіологічних особливостей i господарсько-цінних ознак Salvia verticillata були застосовані польові досліди в комплексі з лабораторними дослідженнями. Вивчали особливості росту і розвитку, морфогенез вегетативних і репродуктивних органів, насінну продуктивність. В період вегетації щодекади 
проводили фенологічні спостереження і біометричні вимірювання (Dospekhov, 1986). Насінну продуктивність визначали за методом Работнова (Rabotnov, 1950) і методичними вказівками з насіннєзнавства інтродуцентів (Emelianov, 1969). Облік врожаю проводили в період масового цвітіння рослин за методикою польових дослідів (Dospekhov, 1986). Сировину зрізували вручну і відразу зважували. Статистичний аналіз проводили за допомогою пакета Агрос (Martynov et al., 2000).

\section{Результати та їх обговорення}

S. verticillata - багаторічні трав'янисті рослини, у яких на зиму вся надземна частина відмирає, а весною з бруньок відновлення відростають нові пагони наступного року. У рослин S. verticillata головний пагін не виражений. Залежно від площі живлення, рослини мають від 1-2 до 7-9 пагонів різної довжини.

Фенологічні цикли росту і розвитку рослин проходять упродовж 8-9 місяців (Рисунок 1). Встановлено, що S. verticillata починає квітувати і плодоносити вже на першому році життя (Cervelli et al., 2011), незалежно від способу розмноження - насінням чи саджанцями. Більшість рослин S. verticillata у перший рік життя зацвітають досить пізно - у серпні.

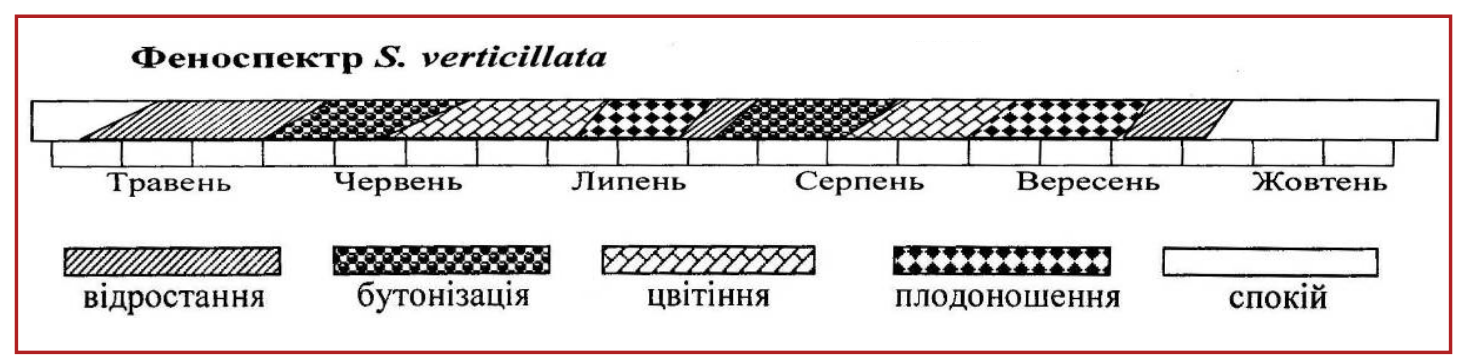

Рисунок 1 Феноспектр рослин виду Salvia verticillata L. на 2-й та подальші роки вегетації

Figure 1 Phase spectrum of plants species Salvia verticillata L. on the $2^{\text {nd }}$ and subsequent years of growth

Фенологічні спостереження показують, що у наступні роки життя рослини S. verticillata схильні до тривалого цвітіння протягом вегетаційного сезону, і мають два максимуми (Рисунок 2а). Перший максимум - у середині червня. Рослини S. verticillata характеризуються високою регенераційною здатністю. Через деякий час після зрізування рослин і збору насіння (Рисунок 2c, d) відростають нові квітконоси і у кінці серпня рослини знову починають квітувати (Cervelli et al., 2011). 
Korablova, O., Rakhmetov, D., Frolova, N., Yushchenko, N., Shanaida, M., Svydenko, L. Agr.bio.div. Impr. Nut., Health Life Qual., 2019, 203-211
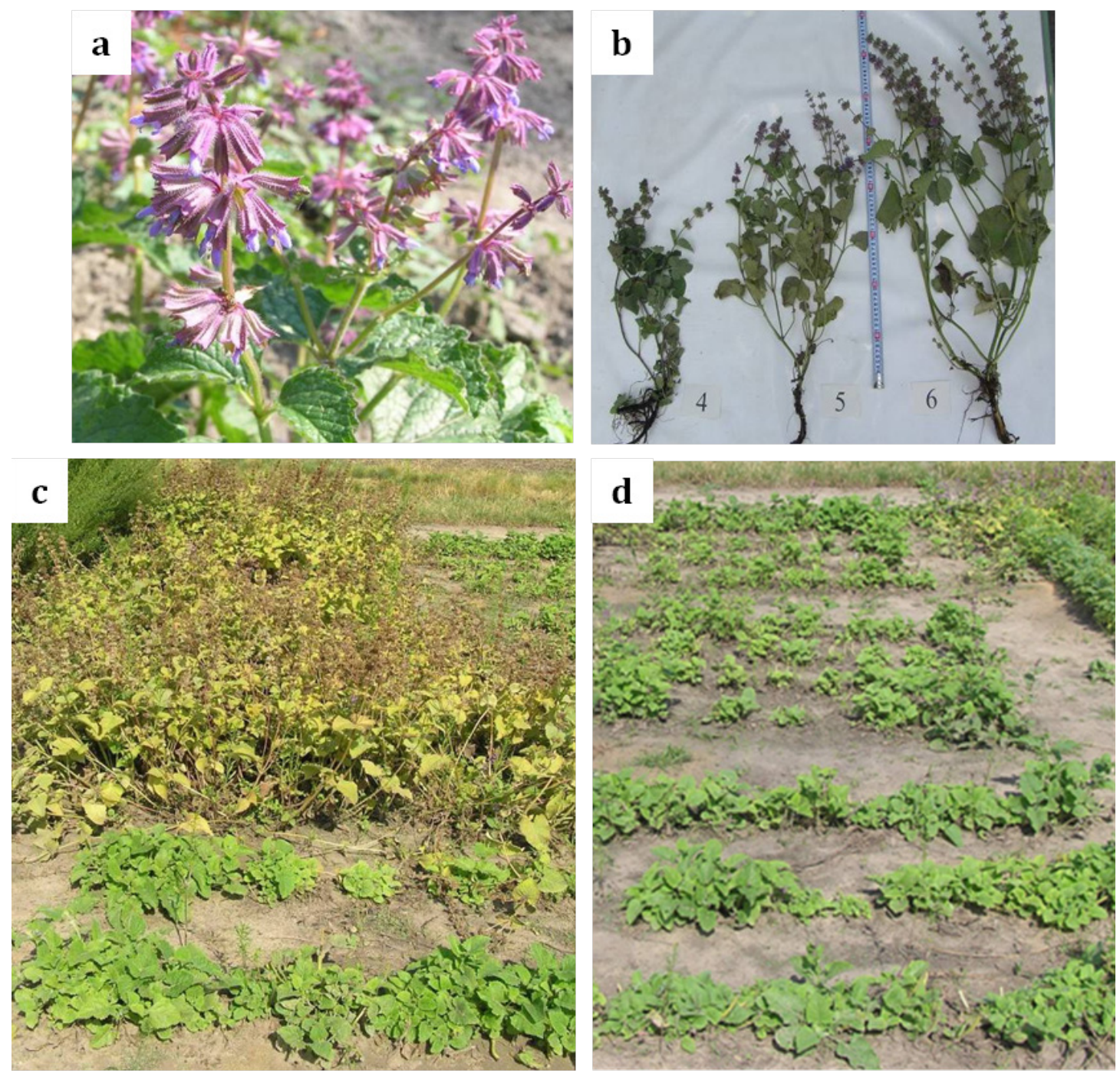

Рисунок 2 Рослини

a - Salvia verticillata L. у фазі цвітіння; b - висота рослин залежно від площі живлення (35, 45, 55 см); c - фаза достигання насіння; d - відростання рослин після скошування

Figure 2 Plants

a - Salvia verticillata $\mathrm{L}$. in the flowering phase; $\mathrm{b}$ - plant height depending on the width of the row spacing ( $35 \mathrm{~cm}, 45 \mathrm{~cm}$ and $55 \mathrm{~cm}$ ); c - the phase of the seeds maturation; $\mathrm{d}$ - plant regrowth after cutting

Біометричні та фенологічні спостереження дозволили встановити адаптаційні можливості рослин, основні закономірності сезонної ритміки росту та розвитку, характерні особливості онтогенезу. Проведено порівняльні дослідження біометричних показників і морфологічних особливостей, визначено кількіснітаякісні характеристики насіння рослин видів S. verticillata власної репродукції (Рисунок 3). 
Korablova, O., Rakhmetov, D., Frolova, N., Yushchenko, N., Shanaida, M., Svydenko, L. Agr.bio.div. Impr. Nut., Health Life Qual., 2019, 203-211

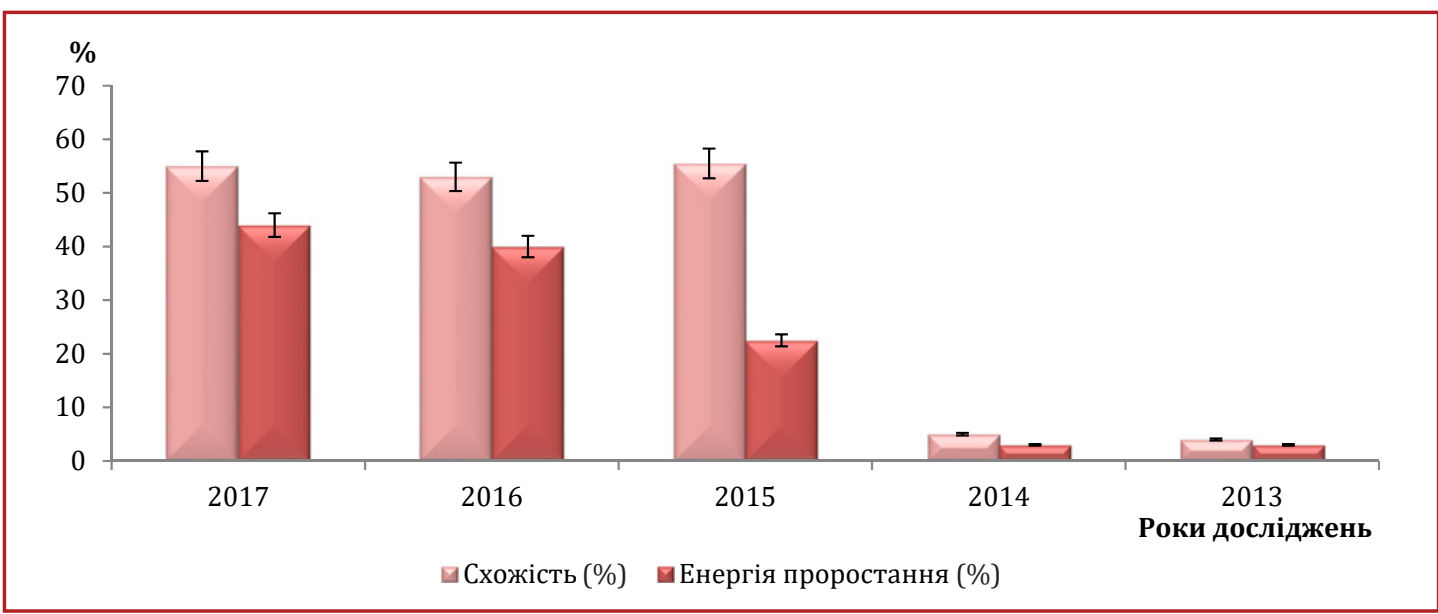

Рисунок 3 Вплив тривалості зберігання насіння Salvia verticillata L. на його схожість та енергію проростання

Figure 3 Influence of the storage period seed Salvia verticillata L. on its germination and germination energy

Встановлено, що маса 1000 шт. насінин виду S. verticillata є досить нестабільною за роками зберігання. У S. verticillata маса 1000 насінин після трьох років зберігання значно зменшується (Dolya et al., 2010). Встановлено, що у перші два роки зберігання насіння $S$. verticillata його схожість тримається на досить високому рівні, на третій рік знижується втричі, на 4-5-й роки проростають поодинокі насінини, а вже на шостий рік схожість дорівнює нулю. Одержані результати свідчать про те, що насіння S. verticillata при зберіганні потрібно оновлювати кожні 2-3 роки, що узгоджується з даними Kovalova et al. (2009).

У лабораторних умовах насіння $S$. verticillata починає проростати на 3-4 добу за температури $+30{ }^{\circ} \mathrm{C}$. У грунті насіння проростає упродовж 18-22 діб. Так при сівбі у середині квітня сходи з'являлися на початку травня, а при сівбі у першій декаді травня - в останній декаді травня.

На дослідних ділянках шавлії кільчастої, закладених насінним та посадковим матеріалом, для встановлення особливостей морфогенетичного потенціалу виду визначали вплив площі живлення на біометричні показники рослин в процесі онтогенезу (Рисунок 2b). Під час біометричних вимірювань рослин S. verticillata враховували пагони довжиною до та понад 50 см. Біометричні дослідження продемонстрували залежність між площею живлення та кількістю генеративних пагонів і кільчаток на рослинах. При площі живлення $35 \times 15$ см рослини мали більш тонкі стебла, проте кількість і коротких, і довгих стебел була вищою ніж за площі $45 \times 15$ см (Таблиця 1). Незначну перевагу за біометричними показниками мають рослини на варіанті з міжряддям $55 \times 15$ см. Вищу продуктивність одержано за рахунок збільшення кількості довгих пагонів на одиниці площі. Встановлено, що загальна кількість пагонів була найменшою за площі живлення $45 \times 15$ см, що цілком узгоджується з показниками урожайності та продуктивності рослин $S$. verticillata 
(Cervelli et al., 2011, Semenchenko et al., 2014). Біометричні показники генеративних пагонів у різних варіантах мало різняться між собою.

Таблиця 1 Кількість та довжина пагонів Salvia verticillata L. залежно від площі живлення Table 1 Number and length of Salvia verticillata L. shoots depending on row spacing

\begin{tabular}{|c|c|c|c|c|}
\hline \multirow{2}{*}{$\begin{array}{l}\text { Ширина } \\
\text { міжряддя }\end{array}$} & \multirow[t]{2}{*}{ Повторність } & \multicolumn{3}{|c|}{ Кількість пагонів (шт./м²) } \\
\hline & & загальна & до $50 \mathrm{~cm}$ & $>50 \mathrm{cM}$ \\
\hline \multirow[t]{3}{*}{$55 \mathrm{~cm}$} & 1 & $163,0 \pm 4,1$ & $54,0 \pm 2,9$ & $109,0 \pm 3,5$ \\
\hline & 2 & $141,0 \pm 3,9$ & $41,0 \pm 2,4$ & $100,0 \pm 3,5$ \\
\hline & Середнє & $152,0 \pm 4,0$ & $47,5 \pm 2,6$ & $104,5 \pm 3,5$ \\
\hline \multirow[t]{3}{*}{$45 \mathrm{~cm}$} & 1 & $85,0 \pm 3,1$ & $29,0 \pm 1,5$ & $56,0 \pm 2,9$ \\
\hline & 2 & $97,0 \pm 3,4$ & $40,0 \pm 2,4$ & $57,0 \pm 2,9$ \\
\hline & Середнє & $91,0 \pm 3,3$ & $34,5 \pm 1,8$ & $56,5 \pm 2,9$ \\
\hline \multirow[t]{3}{*}{$35 \mathrm{~cm}$} & 1 & $122,0 \pm 3,7$ & $56,0 \pm 2,9$ & $66,0 \pm 3,1$ \\
\hline & 2 & $103,0 \pm 3,5$ & $38,0 \pm 2,1$ & $65,0 \pm 3,1$ \\
\hline & Середнє & $112,5 \pm 3,6$ & $47,0 \pm 2,5$ & $65,5 \pm 3,1$ \\
\hline
\end{tabular}

Урожайність і продуктивність надземної маси рослин S. verticillata визначали залежно від площі живлення та кількості скошувань як на фітосировину з гарним біохімічним складом (Korablova et al., 2018), так і для насіння. Після першого літнього скошування рослини добре регенерують і знову проходять фази відростання, бутонізації, цвітіння та дають повноцінне дозріле насіння (Рисунок 4).

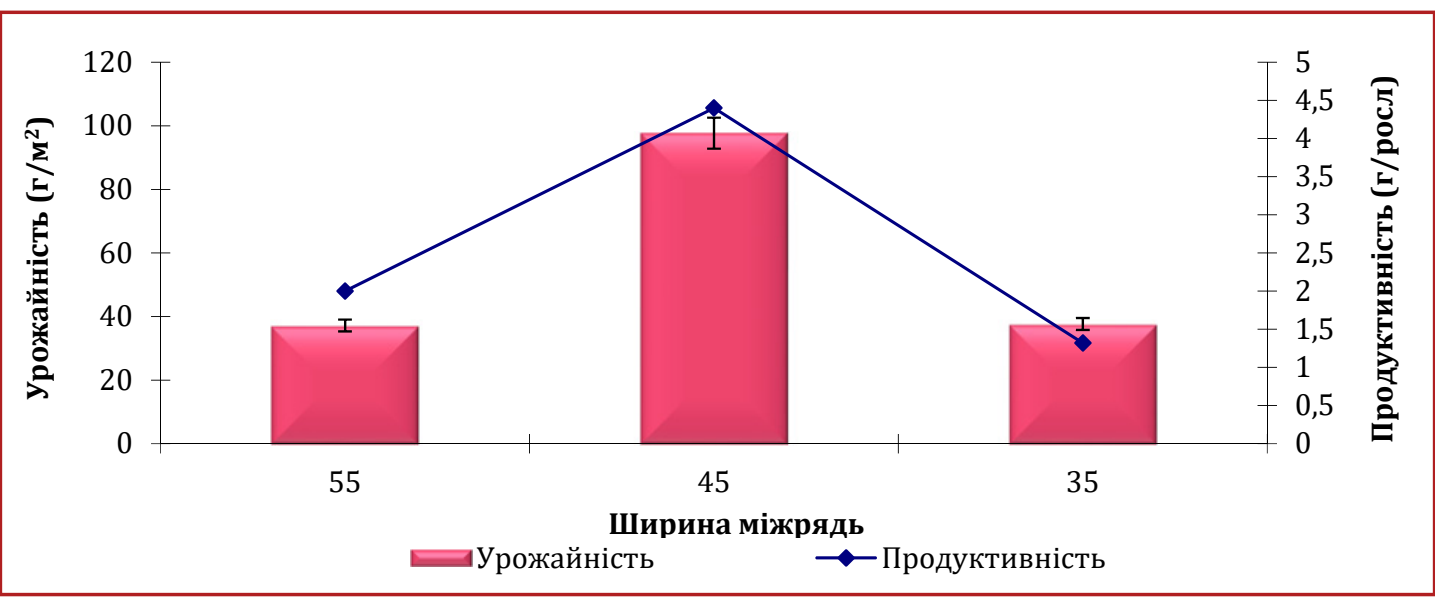

Рисунок 4 Урожайність насіння рослин Salvia verticillata L. та продуктивність залежно від площі живлення

Figure 4 Yield of seeds plants Salvia verticillata L. and their productivity depending on row spacing 
Найвищі показники продуктивності зеленої маси мали рослини, вирощені з міжряддями 55 см. Така ж залежність зберігалася під час другого скошування, але урожайність була на 30-40 \% нижче. Вищу продуктивність одержано за рахунок збільшення кількості і маси великих пагонів на одиниці площі. Продуктивність насіння була вищою за міжрядь у 45 см.

Створено селекційний розсадник перспективних форм S. verticillata, де досліджували формову різноманітність та проводили оцінкупродуктивності тадекоративнихякостей рослин. Аналізували стійкість рослин до ушкодження хворобами та шкідниками. Встановлено, що рослини S. verticillata стійкі до шкідників, проте можуть уражатися борошнистою росою. Біометричні спостереження дозволили встановити адаптаційні можливості, основні закономірності сезонної ритміки росту та розвитку, характерні особливості онтогенезу видів роду Salvia, відібрати перспективні форми рослин. У 2013 році на базі генофонду пряноароматичних рослин та інтродукційних популяцій у НБС НАНУ вперше в Україні створено сорт S. verticillata - Мушкетер, який занесено до Реєстру сортів України у 2016 р. (Derzhavnyi reiestr..., 2018).

За даними досліджень опрацьовано та затверджено в установленому порядку Методику проведення експертизи сортів виду $S$. verticillata на відмінність, однорідність і стабільність. У 2016 році S. verticillata було включено до ТУ України «Зелень пряноароматичних рослин (свіжа і сушена) та їх насіння», які регламентують використання рослинної сировини у харчовій промисловості.

\section{Висновки}

Встановлено, що в умовах Правобережного Лісостепу рослини S. verticillata проходять повний цикл розвитку, дають життєздатне насіння і стабільно здатні до насінного розмноження. Результати досліджень схожості, енергії проростання та маси 1000 шт. насінин залежно від тривалості зберігання свідчать про те, що насіння S. verticillata при зберіганні потрібно оновлювати кожні 2-3 роки.

Таким чином, отримані дані з вивчення біоморфологічних особливостей інтродуцентів роду Salvia у нових умовах мають як наукове, так і практичне значення для добору господарсько-цінних видів, створення нових сортів та збагачення флори України.

Доведено, що сировину рослин виду S. verticillata в умовах Правобережного Лісостепу доцільно заготовляти на технічну переробку під час першого цвітіння, а під час другого - збирати насіння. При роздільному вирощуванні рослин необхідно сівбу на зелену масу проводити з міжряддями 55 см, а на насінниках - доцільно скоротити міжряддя до 45 см.

\section{Література}

AHMED, M., TING, I.P., SCORA, R.W. 2011. Leaf oil composition of Salvia hispanica L. from three geographical areas. In J. Essent. Oil Res., vol. 6(3). p. 223-228. http://dx.doi.org/10.1080/104129 $\underline{05.1994 .9698368}$ 
ATTITALLA, I.H. 2011. Salvia verticillata effects on diabetes and diabetes complications. In Pakistan Journal of biological sciences, vol. 14(24). p. 1130-1131. http://dx.doi.org/10.3923/ pjbs2011.1130.1131

CERVELLI, C., CAPPONI, C., MINUTO, G. et al. 2011. New species and cultivars of Salvia as new ornamental crops. XII Intern. Symposium New floricultural crops: proceeding. Buenos Aires, Argentina. p. 26.

Derzhavnyi reiestr sortiv roslyn, prydatnykh dlia poshyrennia v Ukraini na 2018 rik [State register of plant varieties suitable for dissemination in Ukraine in 2018]. Available at: http://www.sops.gov.ua/ uploads/page/5aa63108e441e.pdf (In Ukrainian)

DOLYA, V.S., MOZUL, V.Y., GOLOVKIN, V.V., FURSA, N.S. 2010. Byoraznoobrazye vydov roda Salvia L. [Biodiversity of species of the genus Salvia L.]. In Farmatsiia Ukrainy. Pohliad u maibutnie: Materialy VII Natsionalnoho zizdu farmatsevtiv Ukrainy, vol. 1, p. 254-255). (In Russian)

DOSPEKHOV, B.A. 1986. Metodyka polevoho opyta [Field Experience Methodology]. Yzd. 5-e, pererab. y dop. Moskva : Ahropromyzdat, 351 s. (In Russian)

EIDI, A., EIDI, M., SHAhMOHAMmADI, P., V. MOZAFFFARIAN, A., RUSTAIYAN, A., MAZOOJI, A. 2011. Antidiabetic effect of Salvia verticillata L. Aerial part in normal and streptozotocin-induced diabetic rats. In International Journal of pharmacology, vol. 7(1), p. 66-73. http://dx.doi.org/10.3923/ ijp.2011.66.73

EMELIANOV, N.P. 1969. Mezhdunarodnye pravyla opredelenyia kachestva semian [International rules for determining the quality of seeds]. Moskva: Kolos. 184 s. (In Russian)

KISELEVA, T.L., SMIRNOVA, YU.A. 2009. Lekarstvennye rasteniya $v$ mirovoy meditsinskoy praktike: gosudarstvennoe regulirovanie nomenklatury i kachestva [Medicinal plants in world medical practice: state regulation of the nomenclature and quality]. Moscow: Prof. assots. naturoterapevtov. (In Russian)

KORABLOVA, O., FROLOVA, N., YUSHCHENKO, N., RAKHMETOV, D., SHANAIDA, M., SEMENCHENKO, O. 2019. Bioecological features of plants species of Salvia L. genus under conditions of the Forest-Steppe zone of Ukraine. Book of Abstracts of the $4^{\text {th }}$ International Scientific Conference Agrobiodiversity for Improve the Nutrition, Health and Quality of Human and Bees Life, vol. 1. Nitra: Slovak University of Agriculture, p. 102. https://doi.org/10.15414/2019.9788055220703

KORABlOVA, O.A., RAKHMETOV, D.B. 2012. Poleznye rastenyia $v$ Ukrayne: Ot yntroduktsyy do yspolzovanyia [Useful plants in Ukraine: From introduction to use]. K.: Fytosotsyotsentr, 171s. (In Russian)

KORABLOVA, O.A., RAKHMETOV, D.B. FROLOVA, N.E., VERGUN, O.M., SEMENCHENKO, O.M. 2018. Mineral composition of plants Salvia verticillata L. and Salvia patens Cav. In Plant Varieties Studying and Protection, vol. 14(4), p. 382-389. https://doi.org/10.21498/2518-1017.14.4.2018.151901

KOVALOVA, A.M., RUSANOVA, A.V., YAKYMENKO, O.M. 2009. Kharakterystyka rodu Shavliia flory Ukrainy [Characteristics of the genus Salvia in the flora of Ukraine]. Farmakohnoziia XXI stolittia. Dosiahnennia ta perspektyvy: Yuvileina nauk.-prakt. konf. z mizhnarodnoiu uchastiu: materialy konf. Kharkiv: b/v. S. 103). (In Ukrainian)

LAWRENCE, B.M. 1992. Chemical components of Labiatae oils and their exploitation. In Advances in Labiatae Science. Eds, R.M Harley and T. Reynolds. Royal Botanical Gardens, Kew, UK. p. 399-436.

LIU, W.J.H. 2011. Traditional Herbal Medicine Research Methods: Identification, Analysis, Bioassay, and Pharmaceutical and Clinical Studies. John Wiley \& Sons (C). www.doi.org.10.1002/9780470921340

MAHDIZADEH, R., MOEIN, S., SOLTANI, N. 2018. Study the molecular mechanism of Salvia species in prevention of diabetes. In International Journal of Pharmaceutical Science and Research, vol. 9(11), p. 4512-4521. https://doi.org/10.13040/IJPSR.0975-8232.9(11)

MARTYNOV, S.P., MUSYN, N.N., KULAHYNA, T.V. 2000. Statystycheskyi y byometryko-henetycheskyi analyz $v$ rastenyevodstve y selektsyy [Statistical and biometric-genetic analysis in crop production and selection]. Paket prohramm AGROS, versyia 2.10. : Rukovodstvo polzovatelia. Tver. $90 \mathrm{~s}$. (In Russian) 
NAGHIBI, F., MOSSADDEGH, M.G., MOHAMED, S.M., GHORBANI, A. 2005. Labiatae Family in folk medicine in Iran: from ethnobotany to pharmacology. In Iranian Journal of pharmaceutical Research, vol. 2, p. 63-79.

OKUNO, Y., MIYAZAWA, M. 2004. Suppressive components in Salvia multiorrhiza against Trp-P-1 and activated Trp-P-1-induced SOS response using Salmonella typhimurium TA1535/pSK1002 Umu test. In Lett. Drug Des. Discov., vol. 1(1), p. 66-68. https://doi.org/10.2174/1570180043485635

RABOTNOV, T.A. 1950. Zhyznennyi tsykl mnoholetnykh travianystykh rastenyi $v$ luhovykh tsenozakh [The life cycle of perennial herbaceous plants in meadow cenoses]. Tr. BYN AN SSSR. Ser. IV, p. 63-74. (In Russian)

RAKHMETOV, D.B., KORABLOVA, O.A., STADNICHUK, N.O., SMILIANETS, N.M., HLABETS, V.Kh. 2015. Kataloh roslyn viddilu novykh kultur [Catalog of plants of the Department of New Cultures]. Kyiv : Fitosotsiotsentr. (In Ukrainian)

SEMENCHENKO, O., TSURKAN, O., KORABLOVA, O. 2014. Chemical composition and in vivo activities of some species of genus Salvia widespread in Ukraine. "Quality and safety in food production chain": $6^{\text {th }}$ International conference, Wroclaw, Poland : Proceeding, p. 138.

SEMENCHENKO, O.M. 2014. Porivnialne doslidzhennia vplyvu deiakykh vydiv rodu Shavliia na riven hliukozy v krovi samtsiv-shchuriv na modeli streptozototsynovoho diabetu (diabet I typu) [Comparative study of the influence some species of the genus Salvia on blood glucose levels in male rats on a model of streptozotocin diabetes (type I diabetes)]. V mizhnar. naukovo-prakt. konf. Medychna nauka ta praktyka XXI stolittia. Zbirnyk mater. Kyiv. s. 111-114. (In Ukrainian) 